\title{
"Digital payment system innovations: A marketing perspective on intention and actual use in the retail sector"
}

\begin{tabular}{|c|c|}
\hline \multirow{3}{*}{ AUTHORS } & Singha Chaveesuk (iD) \\
\hline & Bilal Khalid (iD) \\
\hline & Wornchanok Chaiyasoonthorn (iD) \\
\hline ARTICLE INFO & $\begin{array}{l}\text { Singha Chaveesuk, Bilal Khalid and Wornchanok Chaiyasoonthorn (2021). } \\
\text { Digital payment system innovations: A marketing perspective on intention and } \\
\text { actual use in the retail sector. Innovative Marketing, 17(3), 109-123. } \\
\text { doi:10.21511/im.17(3).2021.09 }\end{array}$ \\
\hline DOI & http://dx.doi.org/10.21511/im.17(3).2021.09 \\
\hline RELEASED ON & Wednesday, 01 September 2021 \\
\hline RECEIVED ON & Friday, 16 July 2021 \\
\hline ACCEPTED ON & Wednesday, 25 August 2021 \\
\hline & $(\mathrm{cc}) \mathrm{EY}$ \\
\hline LICENSE & $\begin{array}{l}\text { This work is licensed under a Creative Commons Attribution } 4.0 \text { International } \\
\text { License }\end{array}$ \\
\hline JOURNAL & "Innovative Marketing " \\
\hline ISSN PRINT & $1814-2427$ \\
\hline ISSN ONLINE & $1816-6326$ \\
\hline PUBLISHER & LLC "Consulting Publishing Company "Business Perspectives" \\
\hline FOUNDER & LLC "Consulting Publishing Company "Business Perspectives" \\
\hline & $\begin{array}{l}= \pm: \\
= \pm=-\end{array}$ \\
\hline NUMBER OF REFERENCES & NUMBER OF FIGURES \\
\hline 73 & 3 \\
\hline
\end{tabular}

(C) The author(s) 2021. This publication is an open access article. 


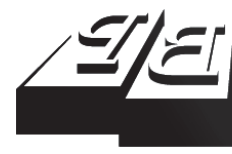

\section{BUSINESS PERSPECTIVES}

()

LLC "CPC "Business Perspectives"

Hryhorii Skovoroda lane, 10, Sumy, 40022, Ukraine

www.businessperspectives.org

Received on: $16^{\text {th }}$ of July, 2021 Accepted on: $25^{\text {th }}$ of August, 2021 Published on: $1^{\text {st }}$ of September, 2021

(C) Singha Chaveesuk, Bilal Khalid, Wornchanok Chaiyasoonthorn, 2021

Singha Chaveesuk, Dr., Assistant Professor, KMITL Business School, King Mongkut's Institute of Technology Ladkrabang, Thailand.

Bilal Khalid, Dr., KMITL Business School, King Mongkut's Institute of Technology Ladkrabang, Thailand. (Corresponding author)

Wornchanok Chaiyasoonthorn, Dr., Associate Professor, KMITL Business School, King Mongkut's Institute of Technology Ladkrabang, Thailand.
This is an Open Access article, distributed under the terms of the Creative Commons Attribution 4.0 International license, which permits unrestricted re-use, distribution, and reproduction in any medium, provided the original work is properly cited.

Conflict of interest statement: Author(s) reported no conflict of interest
Singha Chaveesuk (Thailand), Bilal Khalid (Thailand),

Wornchanok Chaiyasoonthorn (Thailand)

\section{DIGITAL PAYMENT SYSTEM}

INNOVATIONS: A MARKETING PERSPECTIVE ON INTENTION AND ACTUAL USE IN THE RETAIL SECTOR

\begin{abstract}
This study empirically investigated the marketing perspectives of behavioral intention and the actual use of digital payment solutions as electronic innovation for retail purchases in Thailand. This is important as leveraging digital innovation can be applied to minimize physical contact between retailers and customers, especially in the COVID-19 era. The UTAUT model was used and extended to include attitude, social distancing, and perceived risk variables. The study was conducted using primary data collected from 467 Thai respondents who used digital payment systems as a means of payment in retail purchases. The study data were collected employing a structured questionnaire. Techniques used in data analysis include Confirmatory Factor Analysis and Structural Equation Modeling. The results from the data analysis highlighted that behavioral intention to use digital payment innovation in Thailand was influenced by Perceived Risk (PR), Facilitating Condition (FC), Performance Expectancy (PE), and Attitudes (AT) of people. The study also revealed that exploring the marketing perspectives, Behavioral Intention (BI) significantly influenced the Actual Use (AU) of digital payment systems. The implication is that stakeholders in retail and financial sectors, such as banks and other digital payment providers, should consider aspects of people's attitudes and perceived risk as they influence the use and adoption of innovative digital payment solutions. Thus, it is, appropriate to propose policies and regulations that promote the effective use of digital payment systems in the Thai retail sector.
\end{abstract}

Keywords

innovation, behavioral intention, digital payment systems, retail purchases, perceived risk, electronic payment

\section{JEL Classification $\quad \mathrm{C} 12, \mathrm{D} 90, \mathrm{M} 31, \mathrm{O} 31$}

\section{INTRODUCTION}

In the recent past, innovations in information and financial technology have brought about a great revolution, leading to the development and advancement of e-commerce activities. This e-commerce, in turn, has created new fiscal needs that, in most cases, cannot be effectively met by conventional financial systems. Marketing has been instrumental to the spread of these digital technologies, especially on the internet and social media (Dahlström \& Edelman, 2013; Feyen et al., 2021; Fichman, Dos Santos, \& Zheng, 2014; Rangaswamy et al., 2020; Solomon \& Klyton, 2020; Technology and Innovation Report, 2018). From this, various financial institutions, businesses, and other stakeholders are exploring the inherent potential and opportunities resulting from these technologies and are deploying an appropriate marketing strategy to introduce them to the market. Among the notably developed and well-adopted technologies are digital payment systems (Sivathanu, 2019). The digital payment infrastructure consists of an 
interconnected network of related entities, which are designed to accelerate the speed of data exchange between the concerned systems, and to initiate, sanction, and expedite cash transfer between different parties (Scholnick et al., 2008). Digital payments incorporate financial transactions initiated by an individual or several clients, which may cover business-to-business (B2B) transactions, individual-to-business transactions, and person-to-person payments. The intensity of the electronic payments is usually determined by the number of retail transactions to project the volume of digital payments taking place in the country levels. There is a wide range of payment solutions used in digital payments such as Point of Sale (PoS), Automated Teller Machines (ATMs), and other online and mobile banking applications. The consideration of these factors determines the level of adoption of digital payment systems.

Innovative digital solutions imply monetary transactions that are conducted using digital technologies. Through this means of payment, the sender and the recipient of money use digital technology to send and receive payment. Inferring from Nwaolisa and Kasie (2012), this type of financial transaction is also regarded as an electronic payment, which is mainly characterized by the absence of physical cash. Various factors have been considered by researchers to contribute to the growth of digital payments, they include: increased technology, the ever-increasing use of smartphones, institutions starting to offer more non-banking services such as online payments, as well as the adoption of regulations, which supports the growth of these technologies (Yu et al., 2002). Digital payments technology is considered to revolutionize the financial sector by bringing in appealing features such as user-friendliness, convenience, and fast delivery of payment, as compared to manual or traditional payment systems.

As the digital industry continues to develop in Thailand, the impact of Fintech advancement is to present digital payment systems that have revolutionized the business world such as e-money, e-wallet, among other payment systems (Chaveesuk et al., 2018; Kovács et al., 2007). In Thailand, digital payments systems have progressed appreciably in urban communities, and, according to Tounekti et al. (2019), they are used to non-cash payment facilities in their retail purchases. Digital payments are considered to facilitate the ease of the payment process, amid daily and demanding business activities. The most common digital payment systems for transacting payments in Thailand include electronic banking (e-banking), credit cards, debit cards, Prompt Pay, Alipay, PayPal, amongst other electronic payment systems available.

The successful implementation of digital payment systems is critical for the retail sector, especially when considering the transition of Thailand to Web 4.0. The adoption has been greatly aided by the marketing of services, especially digital marketing efforts (Feyen et al., 2021; Nathues, 2017). As a result, understanding customers' requirements and satisfying them in the retail context is important if the success of a digital payment system is considered a priority. Montazemi and Qahri-Saremi (2015) argue that to have increased adoption of digital payment systems, there should be effective management of the factors that influence customers" adoption. Although huge investments have been made in the financial sector in terms of technological innovations; research shows that there is evidence of retail users being reluctant to adopt and use digital payment technologies (Kankanhalli \& Gomez, 2020; Ligon, 2019; Macheel, 2017; Seethamraju \& Diatha, 2019, 2018; Staykova \& Damsgaard, 2016). This highlights the need to investigate the factors influencing the behavioral intention to use and actual use of digital payment systems in the retail sector.

\section{LITERATURE REVIEW AND HYPOTHESES DEVELOPMENT}

Technological developments in the financial industry have led to the emergence of e-com- merce activities such as digital payment systems (Sivathanu, 2019). The infrastructure is made up of an interlinked network of entities, which are meant to increase the speed of data exchange between corresponding e-commerce systems, to expedite, sanction, and initiate data transfer involving two parties. Digital payments involve 
transactions initiated by several clients or individuals, which can encompass person-to-person transactions, individual business payments, and business-to-business transactions (Al-Okaily et al., 2020). The intensity of electronic payments is normally determined by the number of transactions accruable to the project and the number of digital payments taking place at different levels of the country. As defined by Ferguson et al. (2019), digital payments refer to financial transactions carried out using electronic payment methods. In digital payment systems transactions, the receiver and the sender of money both utilize electronic methods to carry out the transactions. Technology in digital payments revolutionized the financial sector by initiating attractive features, including fast, convenient, and responsive delivery of payment solutions, compared to the manual system of payment. Digital payment systems have significantly influenced urban communities and they are used to electronic payments in retail (Singh \& Rana, 2017). The system is considered to make the process of payment easy and convenient during busy and daily activities aided by marketing initiatives.

Several studies have evaluated the adoption of digital technology applications in the financial industry as pertains retail and commercial services. Sivathanu (2019) indicated that it is more than thirty years since the development of communication and information technology, banks now have electronic strategies to improve and facilitate financial transactions and payments optimally to meet business demands of today's world. The Automated Teller Machine (ATM) was introduced in the 1970s, followed by telephone banking. However, the usage rate of electronic banking is less than their rate of development. Concerns such as information disclosure, data safety, and security by third parties and sellers, remain a big issue in electronic banking (Chaveesuk et al., 2019; Raharja et al., 2020). Hoehle (2012) conducted forty-seven article research that focused on consumerism implementation and channels of e-banking, decision assistance tools, and transaction tools, including telephone banking, ATMs, mobile and internet banking. The research showed that for the e-banking option, the Technology Acceptance Model (TAM) framework is more popular than other frameworks. This framework states that the perceived ease and usefulness of the Technology Acceptance Model sets up a series of causality of norms and beliefs about digital technology, actual usage of the technology, attitude toward utilization of technology in addition to the behavioral intentions of applying the technology. It is one of the well-known models used in scientific research and is not only used in its original use.

Muangmee et al. (2021) indicated that performance expectancy (PE) and effort expectancy (EE) have important influences on individuals' behavior and intention towards the usage of technology. Yang et al. (2021), in re-echoing this, acknowledged the significant influence of $\mathrm{PE}$ and $\mathrm{EE}$ on behavioral intention to use technology services, and similarly, behavioral intention (BI) and facilitating conditions (FC) shape deployment of technology and have been applied in technology adoption models such as UTAUT. Different studies have applied the UTAUT model due to the wide use of Technology Assistive Models in e-banking, online shopping, e-commerce, and for comparison. According to DesRoches (2013), factors that affect the utilization of e-banking are reliability, friendliness, valuableness, and easiness. The critical factor that affects the use of e-banking channels is consumer trust (Howcroft, 2003). The high security of e-banking channels enhances trust, good trust perception, and these are likely to enhance the use of e-commerce platforms. Other studies investigated dynamics that prompt the embracing of e-banking based on the collected data from clients and customers of public and private banks (Wong \& Mo, 2019; Yang et al., 2021; Yu et al., 2002).

The Unified Theory of Acceptance and Use of Technology (UTAUT) refers to a framework formulated for the adoption by users of information technology. The model attempts to clarify the intention of a user to utilize a given information system, as well as user behavior. The model avers that there are four main constructs: 1) performance expectancy 2) effort expectancy 3) social influence (SI), and 4) facilitating conditions (Khalid et al., 2021; Williams et al., 2015). Yang et al. (2021) stated that facilitating conditions does not significantly influence consumers' intentions to utilize electronic wallet (e-Wallet) as their favored payment solution. In dissonance, Peñarroja et al. (2019) found that FCs can foster consumer's inten- 
tion to use digital payment solutions using online platforms. They ascertained the insignificant influence of facilitating conditions in specific cultural and environmental settings as the prevailing substructure does not reinforce such services (Iskandar et al., 2020).

According to Sanayei and Noroozi (2009), perceived risk (PR) is prediction, valuation, or information inadequacy concerning the spread of likely outcomes and their attainment of controllability. Chiou et al. (2011) view PR as the condition of being unaware concerning something or the absence of awareness concerning the circulation of results and the condition in which there is the unpredictability of the final result attainment. In the scenario of repayment services, customers have the awareness that disclosing their credit card information is risky but there are no restrictions on it. Wong and Mo (2019) stated that consumer perceptions of service as being reliable and honest increases the consumers" intention to utilize the service because of the high levels of conviction in the products and services on offer. Therefore, consumers' trust significantly influences the intention to use the technology.

Under the notion of perceived usefulness, the strong conviction of a person that adopts technology is expected to fulfill their result outcomes. Chen et al. (2011) then assessed how much-perceived ease of use (PEOU) and perceived usefulness (PU) affected BI and if the effect is significant. The study concluded that PU strongly influences BI. According to TAM, PU and PEOU influence behavior by the way they are handled in the system of information. This developed behavior networks that analyze the intention of a person and results in the acceptance of the technology. Pikkarenen et al. (2004) used Technology Acceptance Model in Finland to determine that perceived usefulness is the key determinant of real behaviors that trigger bank customers towards utilizing comprehensive and modern e-banking and it offered increased independence and autonomy in financial transactions.

Davis (1989) portrays PEOU as the extent to which an individual trusts that utilization of a given technology system will be free. Perceived ease of use refers to any task that is carried out effortlessly.
A study was carried out to discuss how the perception of users concerning online banking is impacted by the privacy policy and the PEOU. Goodrich and Boer (2003) concluded that PEOU cannot be of great significance when compared with security and privacy. Roboff and Charles (1998) contended that PEOU does not directly influence attitude intention though it was influenced more by a factor of indirect mediation from perceived use. PEOU states their insight and understanding of the process that leads to the result. Chin and Ahmad' (2015) findings showed that PEOU is crucial in determining consumer intent to use an e-payment system of. Hence, PEOU can be utilized as an intermediary of perceived enjoyment.

\section{AIM}

Using the cited literature as a guide and research gaps on the implementation of digital payment systems in Thailand, the study aimed to investigate the factors that influence $\mathrm{BI}$ in the use of digital payment solutions as well as the actual use of innovative digital payment solutions in the retail sector in Thailand from a marketing perspective. Understanding these factors will influence stakeholder effort towards a seamless digital transaction experience both for consumers and retailers. Banks and other financial institutions can leverage these factors when developing digital payment solutions or improve the already existing technologies to meet the expectations of the 21st century. The conceptual framework for the study was developed based on the analyzed literature that guided the study. The conceptual model is shown in Figure 1.

The above conceptual model shows six independent variables, namely PE, EE, SI, FCs, SD, and PR. The study incorporated two dependent variables such as behavioral intention to use and actual use. The model integrated a mediating variable, attitude, which mediates the correlation between behavioral intention to use, and two independent variables such as performance expectancy and effort expectancy. The positive and significant role of performance expectancy and effort expectancy as direct determinants of behavioral intention in the adoption of technology has been validated in many studies (Chao, 2019; Hoque \& Sorwar, 


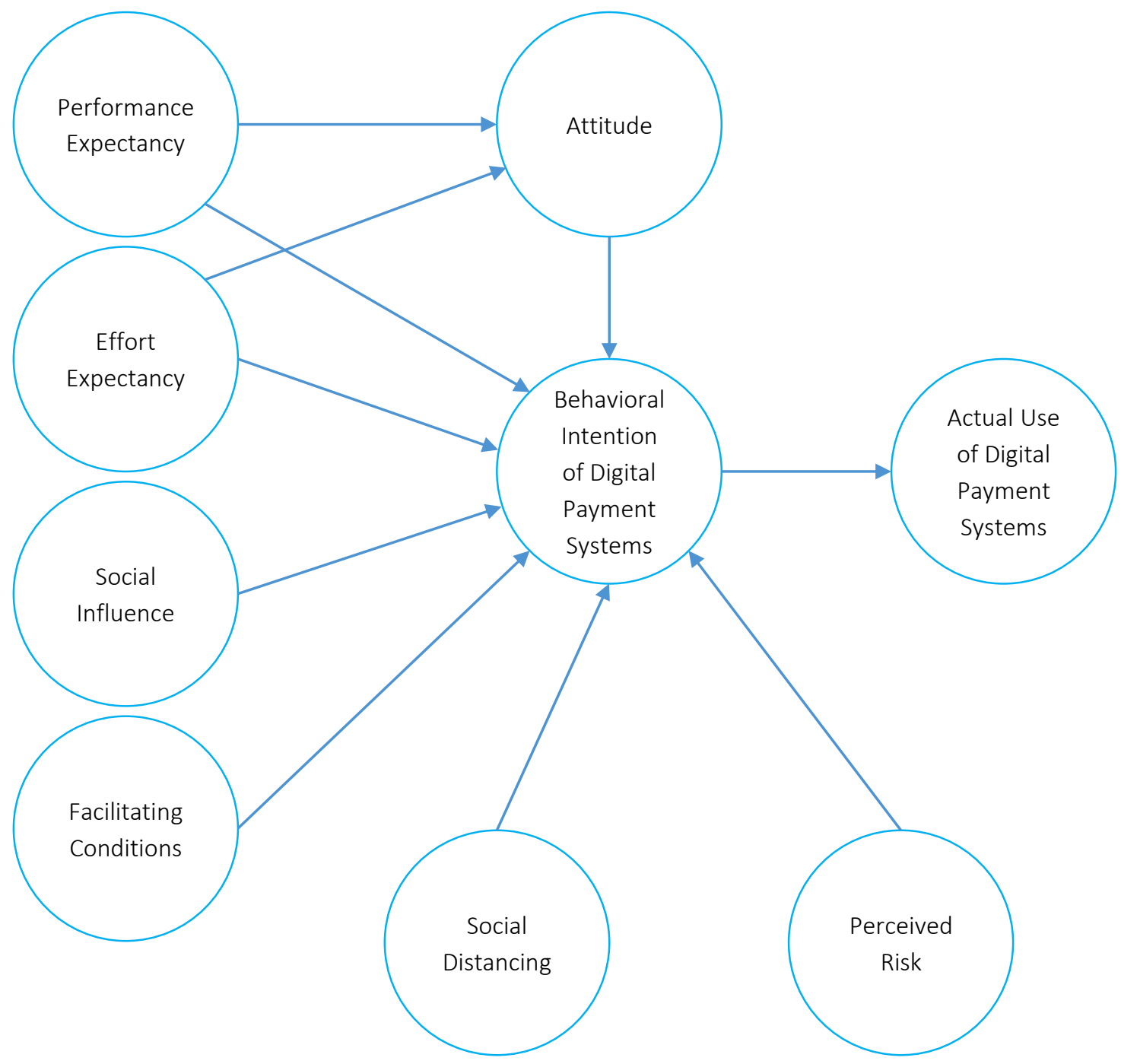

Figure 1. Conceptual framework

2017; Muangmee et al., 2021; Yang et al., 2021). Venkatesh et al. (2003) defined performance expectancy as "the degree to which an individual believes that the system helps to improve job performance" (p. 447), while effort expectancy was defined as "the degree of ease associated with the use of the system" (p. 157). This study tests the consistency of these hypotheses in the adoption of digital payments and provides insight into how $\mathrm{PE}$ and EE correlate with BI to use digital payments systems in Thailand. The measurement scales for $H 1$ and $H 2$ were adopted from Chao (2019).

Yang et al. (2021) inform that SI denotes the extent to which consumers recognize the influence of relationships such as friends, family, and colleagues in their decisions, especially pertaining the adoption of a specific technology or service.
Social influence can be applied when discussing the perception of technological innovations and the level of importance placed on them by the individuals concerned. Previous research claimed that social influence significantly affects a user"s BI to use innovative technologies (Ali \& Arshad, 2018; Al-Hujran et al., 2014; Venkatesh et al., 2003). Inferring from this, social influence was integrated into this study that investigates the intention to use digital payment systems in Thailand. The measurement scales for $\mathrm{H} 3$ were adopted from Ali and Arshad (2018).

Venkatesh et al. (2003) stated that a FC is the extent to which the technical components and existing organizational infrastructure can reinforce the presence of new innovative technology for an individual. Prior literature has supported the pos- 
itive and significant influence of facilitating conditions on the adoption of technological innovation (Ali \& Arshad, 2018; Iqbal \& Qureshi, 2012). This study, therefore, investigates the applicability of the hypothesis to the adoption of digital payment systems to ascertain if the findings will be consistent with those in previous studies identified by this study. The measurement scales for $\mathrm{H} 4$ were adopted from Ali and Arshad (2018).

Pearce (2020) defines social distancing as "a public health practice that aims to prevent sick people from coming in close contact with healthy people to reduce opportunities for disease transmission." Social distancing became more pronounced with the outbreak of the COVID-19 pandemic, it is a set of measures where a certain distance is maintained between people in public to curtail the spread of a contagious disease. This was the case of COVOID-19; the world is still recovering from the effects of the pandemic with increasing infections brought about by new variants of the virus. Daragmeh et al. (2021), agreeing with Kleczkowski et al. (2015), acknowledged the significance of social distancing in the adoption of mobile payment solutions by including in their findings that $\mathrm{SD}$ raised awareness about the seriousness of the COVID-19 virus and has made consumers consider the adoption of digital payments to minimize personal contact with others in order to avoid being infected with the virus. The measurement scales for $\mathrm{H} 5$ were adopted from Kleczkowski et al. (2015).

The experiences, marketing, and word of mouth form the core of service expectations from users who patronize a brand or product. Service quality assesses and compares perceived and expected services; studies have applied the TAM model to evaluate perceived risk (Shiau \& Chau, 2016; Zhang \& Yu, 2020). Lim (2014) added that perceived risk, together with PU and PEU, significantly affects intention to use innovative technology. From Wei et al. (2018), uncertainties associated with perceived risk directly affect the purchasing intent of consumers. Juxtaposing this study, the hypothesis is proposed that $\mathrm{PR}$ has a positive and significant effect on behavioral intention to use digital payment systems. The measurement scales for H6 were adopted from Chao (2019).
Behavioral intention is the measure of the strength of an individual's intention to execute a particular behavior (Fishbein \& Ajzen, 1975). In research on technology adoption, strong behavioral intentions regarding the use of innovation will indicate one's acquiescence and deployment of the technology (Chao, 2019; Khalid et al., 2021; Yi et al., 2006), and this measure is central in the assessment of the relationship between BI and actual use of digital payment solutions in Thailand, and how significant and positive they are. The measurement scales for $H 7$ were taken from Chao (2019).

Attitude was defined as the acquired susceptibility to constantly respond positively or negatively about a given object or a point of view (Ajzen \& Fishbein, 1980). The significant influence of attitude and its impact on the acceptance of innovative technological advancements have been discussed in some studies (Huang \& Liaw, 2005; Sang et al., 2010; Teo et al., 2009). Emergent from these prior studies, this study attempts to reprise the influence of attitude by investigating if it has a positive and significant influence on BI in using digital payment systems in Thailand. The measurement scales for $H 8$ were taken from Hussein (2017). The following hypotheses were developed based on the existing literature analyzed:

H1: Performance expectancy has a positive and significant influence on behavioral intention to use digital payment systems.

H2: Effort expectancy has a positive and significant influence on behavioral intention to use digital payment systems.

H3: Social influence has a positive and significant effect on behavioral intention to use digital payment systems.

H4: Facilitating condition has a positive and significant influence on behavioral intention to use digital payment systems.

H5: Social distancing has a positive and significant influence on behavioral intention to use digital payment systems.

H6: Perceived risk has a positive and significant influence on behavioral intention to use digital payment systems. 
H7: Behavioral intention has a positive and significant influence on actual use.

H8: Attitude has a positive and significant influence on behavioral intention to use digital payment systems.

\section{METHODS}

This section discussed the methods adopted in the analysis and presentation of the results. The first part was a critical review of the literature on research conducted in the research areas of interest and reference to the adopted UTAUT model. This helped in identifying the study variables and developing research hypotheses.

The study was conducted using primary data. The data were collected using online surveys administered through Google forms. The data were collected from the people living in Bangkok province of Thailand as they were most familiar with using digital payment systems in their retail transactions. The study population consisted of people using or having experience with digital payment systems in their retail transactions such as QR codes, online banking, and mobile payments. A sample of 500 respondents was selected from the population from whom data was collected. A convenience sampling technique was adopted to identify people who have used digital payment systems in their retail purchases and transactions. Data was collected between August 5, 2020, and January 23, 2021.

A structured questionnaire was used to collect data from the respondents. The questionnaire consisted of two sections. The first section contained questions regarding the demographic characteristics of respondents, including age, gender, and occupation. The second section of the questionnaire contained questions regarding the study variables such as performance expectancy (PE), effort expectancy (EE), social influence (SI), facilitating conditions (FC), social distancing (SD), perceived risk (PR), attitude (AT), behavioral intention to use (BI) and actual use (AU). To ensure the validity of the questionnaire, it was submitted to five experts to validate its appropriateness. The questionnaire was designed using a 5-point Likert scale where $1=$ strongly disagree and $5=$ strongly agree. Once the data was collected, it was evaluated for missing values and outliers. A total of 467 responses were collected, after cleaning the data, a total of 400 responses were validated for analysis.

The data were analyzed using several techniques. The first technique was reliability and validity tests that evaluated the fitness of the model. Another technique adopted was Confirmatory Factor Analysis (CFA) that evaluated the suitability of the model. The relationship between the variables was evaluated using Structural Equation Modeling (SEM). The findings of the analysis were used to develop the discussions and conclusions of the study.

\section{RESULTS}

The preliminary result involved the descriptive statistics of the demographic characteristics of the respondents such as gender, age, education level, occupation, monthly income (in THB), and the digital payment system adopted by the respondents. The results are presented in Table 1 and discussed in the following section.

From the data, female respondents were the majority $(63.7 \%)$ and males were $36.3 \%$. The highest age group was 21-30 years comprising $56 \%$, followed by those below 20 years accounting for $19.8 \%$. Among the three education levels considered, the highest level was bachelor's degree (60.5\%) and below bachelor's education accounting for $20.5 \%$. The occupation of the respondents was evaluated, and the highest was company employed comprising $37.3 \%$, followed by students comprising $35.3 \%$. The government officer respondents accounted for $9.5 \%$. The monthly income of the respondents showed that the highest were those earning below 15,000 THB accounting for $35.3 \%$,followed by those earning between 20,001 and 30,000 THB accounting for $26 \%$. The digital payment system consisted of internet banking, mobile banking, tablet application, and mobile application. The largest proportion were those using a combination of mobile app and internet banking (44\%), followed by those using only mobile banking (36\%). This 
Table 1. Demographics and respondent adoption of digital payments

\begin{tabular}{|c|c|c|}
\hline Gender & $\mathbf{n}$ & $\%$ \\
\hline Male & 145 & 36.3 \\
\hline Female & 255 & 63.7 \\
\hline \multicolumn{3}{|l|}{ Age } \\
\hline $18-20$ years & 79 & 19.8 \\
\hline $21-30$ years & 224 & 56 \\
\hline $31-40$ years & 63 & 15.8 \\
\hline $41-50$ years & 34 & 8.5 \\
\hline \multicolumn{3}{|c|}{ Highest Education Level } \\
\hline Below Bachelor & 82 & 20.5 \\
\hline Bachelor's Degree & 242 & 60.5 \\
\hline Master's Degree & 76 & 19 \\
\hline \multicolumn{3}{|c|}{ Occupation } \\
\hline Student & 141 & 35.3 \\
\hline Employment & 44 & 11 \\
\hline Self-employed & 28 & 7 \\
\hline Private company employed & 149 & 37.3 \\
\hline Government officer & 38 & 9.5 \\
\hline \multicolumn{3}{|c|}{ Monthly Income in THB } \\
\hline Below 15,000 & 129 & 32.3 \\
\hline $15,001-20,000$ & 1 & 0.3 \\
\hline $20,001-30,000$ & 104 & 26 \\
\hline $30,001-40,000$ & 62 & 15.5 \\
\hline $40,001-50,000$ & 60 & 15 \\
\hline Above 50,000 & 44 & 11 \\
\hline \multicolumn{3}{|c|}{ Digital payment systems } \\
\hline Internet banking & 68 & 17 \\
\hline Mobile banking & 144 & 36 \\
\hline Mobile app \& internet banking & 176 & 44 \\
\hline $\begin{array}{l}\text { Mobile app, tablet app, and internet } \\
\text { banking }\end{array}$ & 12 & 3 \\
\hline
\end{tabular}

section presents the model evaluation, this was to ensure that the constructs used in the study, the data collected, and the adopted model were suitable to give objective findings of the study. Several model evaluation methods were used such as the Confirmatory Factor Analysis (CFA), reliability analysis, and validity analysis (they are discussed in the following section).

The first analysis conducted was reliability analysis. In this analysis, the observed variables constructs were evaluated to determine if they were appropriate for the analysis. Reliability was evaluated using Cronbach's Alpha. The results show that the Cronbach's Alpha for the overall constructs was 0.936 , which is excellent. When evaluating the independent observables in the Cronbach's Alpha if item deleted section, all constructs in the 0.934 to 0.937 range were found to be excellent. The results confirmed that the constructs were reliable for the study.
Reliability and validity of the model were also evaluated using the Composite Reliability (CR) and Average Variance Extracted (AVE) (Table 2). According to Figure 2, CR for all variables was above 0.70 and AVE higher than 0.5 (Fornell \& Larcker, 1981). Also, given that the Cronbach's Alpha was excellent, the reliability and validity of the variables are considered to meet the threshold in Fornell and Larcker (1981).

Table 2. Reliability and validity statistics Composite reliability and average variance extracted

\begin{tabular}{c|c|c}
\hline Variables & CR & AVE \\
\hline$P R$ & 0.806 & 0.580 \\
\hline$B I$ & 0.739 & 0.567 \\
\hline$A U$ & 0.817 & 0.599 \\
\hline$A T$ & 0.874 & 0.583 \\
\hline$E E$ & 0.898 & 0.639 \\
\hline$S I$ & 0.755 & 0.607 \\
\hline$F C$ & 0.879 & 0.645 \\
\hline$S D$ & 0.715 & 0.518 \\
\hline$P E$ & 0.846 & 0.580 \\
\hline
\end{tabular}

The last evaluation of the model was carried out using Confirmatory Factor Analysis (CFA). This was intended to assess how well the measured constructs represent the number of constructs. The CFA model is shown in Figure 2.

The Fit indices reported by the CFA results were as follows: $p$-value $=0.000, \mathrm{CFI}=0.903$, TLI $=$ 0.891 , $\mathrm{IFI}=0.904, \mathrm{NFI}=0.805, \mathrm{RMSEA}=0.067$, and $X 2 / \mathrm{df}=2.768$. From the above results, CFI, TLI, IFI, and NFI were all approximately greater or equal to the 0.9 goodness of fit threshold ( $\mathrm{Hu}$ \& Bentler, 1999). Additionally, the most reliable measure of the chi-square ratio to degrees of freedom was below $5.0(X 2 / \mathrm{df}=2.768)$. Furthermore, the square root of the difference between the residuals of the sample covariance matrix and the hypothesized model (RMSEA) was below the cut-off threshold of 0.08 . Therefore, these indices indicated that the proposed SEM model was fitting well with the study variables (Cselényi et al., 2002; Hu \& Bentler, 1999).

After confirming the reliability and validity of the constructs, and the fitness of the proposed model in the previous sections, the next step was to carry out the Structural Equation Modeling (SEM). SEM was aimed at evaluating the research hy- 


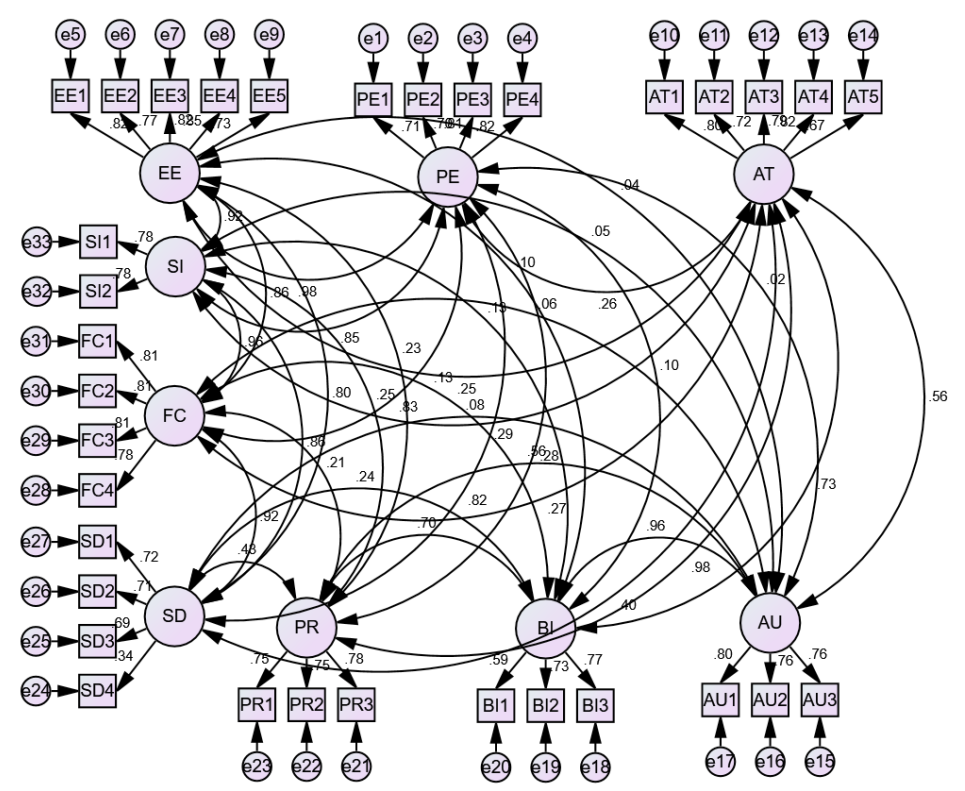

Figure 2. Confirmatory factor analysis

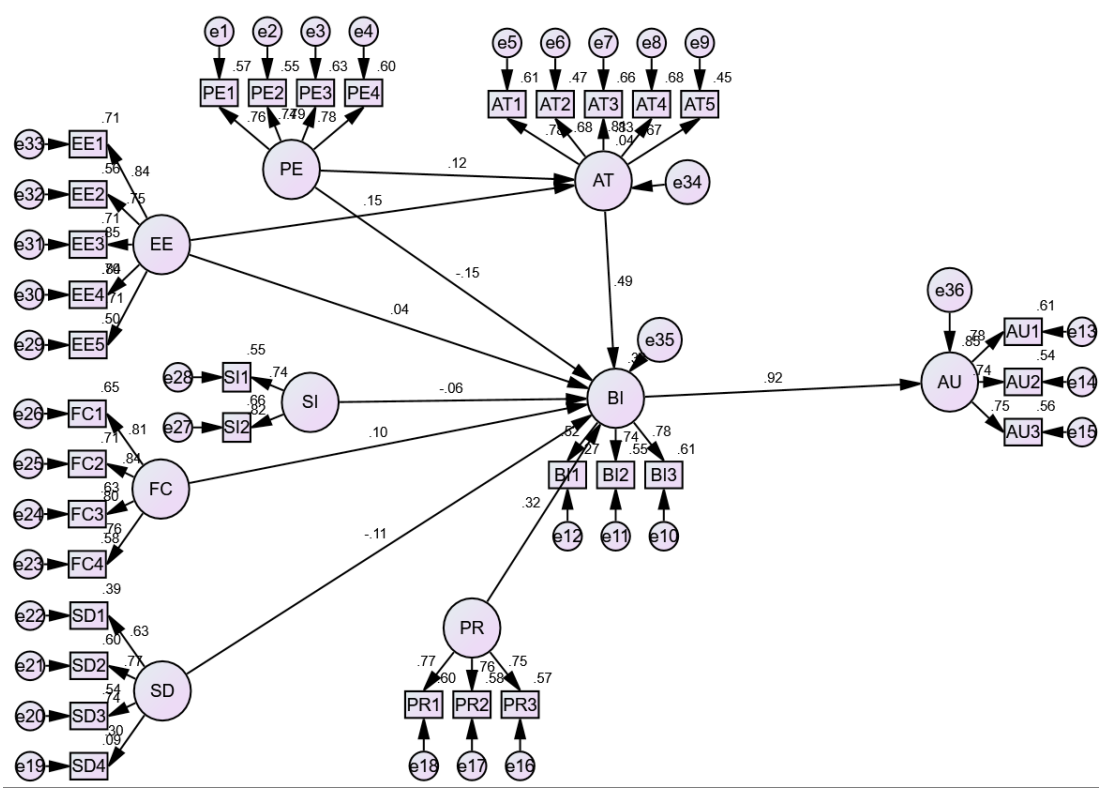

Figure 3. Structural equation model analysis

pothesis and achieving the objectives of the study. The SEM analysis results are presented in Figure 3 and Table 3.

From the model, the dependent variables include behavioral intention to use (BI) and actual use (AU) of the digital payment systems. Considering the direct effects, Table 3 shows that four variables significantly influenced behavioral intention to use BI. Perceived risk (PR) has a positive and significant influence on $\mathrm{BI}$ $(\beta=0.318, p<0.01)$. Facilitating condition (FC) has a positive and significant influence on $\mathrm{BI}(\beta$ $=0.103, p<0.05)$, performance expectancy $(\mathrm{PE})$ has a negative and significant influence on $\mathrm{BI}(\beta$ $=-0.150, p<0.01)$, and attitude $(\mathrm{AT})$ has a positive and significant influence on $\mathrm{BI}(\beta=0.500, p$ $<0.01)$. The study also indicated that behavioral intention (BI) has a significant influence on the actual use (AU) of digital payment systems. It is also important to note that performance expectancy (PE) and effort expectancy (EE) has a significant influence on attitude (AT) $(\beta=0.121$, $p<0.05)$ and $(\beta=0.121, p<0.01)$, respectively. 
Table 3. Evaluation of study hypotheses

\begin{tabular}{|c|c|c|c|c|}
\hline Paths & Estimate & S.E. & C.R. & $\mathbf{P}$ \\
\hline \multicolumn{5}{|c|}{ Direct Effects } \\
\hline $\mathrm{AT} \leftarrow \mathrm{EE}$ & .168 & .062 & 2.695 & $* * *$ \\
\hline $\mathrm{AT} \leftarrow \mathrm{PE}$ & .121 & .058 & 2.098 & $* *$ \\
\hline $\mathrm{BI} \leftarrow \mathrm{PR}$ & .318 & .055 & 5.745 & $* * *$ \\
\hline $\mathrm{BI} \leftarrow \mathrm{SD}$ & -.275 & .145 & -1.891 & .059 \\
\hline $\mathrm{BI} \leftarrow \mathrm{FC}$ & .103 & .050 & 2.049 & $* *$ \\
\hline $\mathrm{BI} \leftarrow \mathrm{SI}$ & -.056 & .059 & -.962 & .336 \\
\hline $\mathrm{Bl} \leftarrow \mathrm{EE}$ & .051 & .057 & .891 & .373 \\
\hline $\mathrm{Bl} \leftarrow \mathrm{PE}$ & -.150 & .053 & -2.817 & $* * *$ \\
\hline $\mathrm{BI} \leftarrow \mathrm{AT}$ & .500 & .059 & 8.437 & $* * *$ \\
\hline $\mathrm{AU} \leftarrow \mathrm{BI}$ & .882 & .065 & 13.589 & $* * *$ \\
\hline \multicolumn{5}{|c|}{ Indirect Effects } \\
\hline $\mathrm{BI} \leftarrow \mathrm{AT} \leftarrow \mathrm{EE}$ & .047 & .051 & .047 & $* * *$ \\
\hline $\mathrm{BI} \leftarrow \mathrm{AT} \leftarrow \mathrm{PE}$ & .168 & .190 & .168 & $* *$ \\
\hline
\end{tabular}

Note: ${ }^{* *}=$ significant at $0.01 ; * *$ significant at $0.05 ; \mathrm{AT}=$ attitude; $\mathrm{EE}=$ effort expectancy; $\mathrm{PE}=$ performance expectancy, $\mathrm{BI}=$ behavioral intention, $\mathrm{PR}=$ perceived risk, $\mathrm{SD}=$ social distancing, $\mathrm{FC}=$ facilitating conditions, $\mathrm{SI}=$ social influence, $\mathrm{AU}=$ actual use.

The mediating effect of attitude (AT) between $\mathrm{PE}$ and $\mathrm{BI}$ and EE and BI showed significant results. AT was found to positively and significantly mediate the relationship between $\mathrm{EE}$ and BI $(\beta=0.047, p<0.01)$ and PE and BI $(\beta=0.168$, $p<0.05)$.

\section{DISCUSSION}

This model was aimed at evaluating the BI and actual use of digital payment systems for retail purchases in Thailand from a marketing perspective by applying the UTAUT model. The research focus was to evaluate the factors influencing behavioral intention to use innovative digital payment systems in Thailand. From the findings, 'attitude' has the highest positive influence on behavioral intention to use digital payment systems $(\beta=0.500, p<0.01)$. This implies that if the attitude of the respondents towards digital payment systems increased by one unit, then behavioral intention to use would increase by 0.5 units. These results confirmed $H 8$ that attitude has a positive and significant influence on behavioral intention. The second factor in rank was the perceived risk. The results indicated that if perceived risk increased by one unit, the behavioral intention to use digital payment system increased by 0.318 units, which confirmed $\mathrm{H} 6$ of the study that perceived risk has a positive and significant influence on behavioral intention to use digital payment systems.
The results on perceived risk support the results in Ho et al. (2020), though their analysis indicated the indirect but positive and significant effect on behavioral intention to use mobile banking. The findings are also in line with Wong and Mo (2019) who opined that consumers' perception of service as being reliable and honest correspondingly increases the intention to make use of the service because of high levels of confidence in the services being offered. Thus, consumers' trust can significantly influence the intention to use digital payment solutions as a hallmark of innovation in the retail services business. Trust in digital technologies supports improved appraisals and attitudes towards digital payment solutions that are seen as an innovation, especially those in which the technology benchmarks fulfill all set obligations and are trustworthy and relatively meet all safety requirements and protocols, which will, in turn, have a positive influence on the consumers' intention to use such technologies.

Performance expectancy was found to have a negative and positive effect, inferring that a one-unit increase in performance expectancy would lead to a 0.150 unit decrease in behavioral intention to use innovative digital payment solutions. This partially confirmed $\mathrm{H} 1$ of the study. Thus, the findings by Muangmee et al. (2021) that PE and EE have an important effect on human behavior and the intention to use technology are partially confirmed and applicable in this case. Yang et 
al. (2021) recognized a significant influence of PE and $\mathrm{EE}$ on behavioral intention to use technology, while BI and FCs determine technology use and have been applied in technology adoption models, including digital payment solutions and internet banking.

The results also indicated that a one-unit increase in FC would lead to a 0.103 unit increase in the BI to use digital payments; this confirmed $H 4$ of the study that FC has a positive and significant influence on BI. These results were congruent with Lin et al. (2020) who found out that SI, FCs, hedonic value, adaptability, technology, perceived benefits, and reliability positively influence consumer intention to use a mobile system of payment. It is critical to note that the social influence, social distance, and effort expectancy variables did not significantly influence the behavioral intention to use digital payment. However, this was not consistent with findings of Yang et al. (2021), who found that FCs did not significantly influence consumer intent to use digital payment solutions as their preferred method of payment based on their analysis. This study demonstrated a different outcome from Peñarroja et al. (2019). It highlights that FCs can motivate a consumer to use digital payment solutions using online platforms. They made it certain that the influence of FCs in specific cultures and environments is not substantial because the prevailing substructure does not reinforce such services (Iskandar et al., 2020).

However, these results were in conflict with those of Yang et al. (2012), who found that social influence had a significant influence on behavioral intention to use mobile payment services. According to their results, societal influence, for example, from friends, relatives, and other colleagues in the peer group, primarily affects the mindset of consumers, especially with regard to products considered innovative and new to the market, through digital and technological services. Social influence is considered the second most effective factor of consumers' intentions; it is, therefore, vital to encourage consumers' intentions to apply digital payment solutions, since it can foster emotive and coherent viewpoints among consumers in countries such as Thailand. As a result, $\mathrm{H} 2, \mathrm{H} 3$, and $\mathrm{H} 5$ were rejected. The study also evaluated the relationship between behavioral intention to use digital payments and actual use of digital payments. According to the findings, a unit increase in behavioral intention would result in a 0.882 increase in the actual use of digital payments in Thailand.

\section{CONCLUSION}

The purpose of this study was to investigate the marketing perspectives of the behavioral intention and actual use of digital payment systems for retail purchases in Thailand. The study is important due to continuous developments in information and financial technology, which has led to advances in e-commerce and inventions, including digital payment technologies. The findings show that Perceived Risk (PR), Facilitating Conditions (FC), Performance Expectancy (PE), and Attitude (AT) significantly influenced behavioral intention to use digital payments in Thailand. The results also highlighted the significant influence of Behavioral Intention (BI) on the Actual Use (AU) of innovative digital payment systems.

This study has both theoretical and managerial implications. First, the UTAUT model was adopted and extended by including other variables such as social distancing perceived risk and attitude as constructs. Including these variables in the model provides valid observations of the results. Second, other studies could adopt this model to compare and evaluate the results. When considering managerial implications, two aspects stand out: perceived risk and attitude. Both variables significantly influence BI to use and the actual use of innovative digital payment solutions in the retail sector. Stakeholders in the financial sector and financial institutions need to consider the aspects of people's attitudes and perceived risk as they influence the adoption and use of digital payment systems in the retail sector. The study is limited by the fact that it was originally conducted in Thailand, so the application of the findings to other areas should be considered with caution. 
Another aspect is that the study was conducted at a time when digital payment systems were emphasized as a means of controlling the spread of COVID-19. Consequently, these specific circumstances may have impacted the results of the study. Therefore, these conditions limit this study and should be considered when summarizing the study findings and in future studies.

\section{AUTHOR CONTRIBUTIONS}

Conceptualization: Singha Chaveesuk, Bilal Khalid, Wornchanok Chaiyasoonthorn.

Data curation: Singha Chaveesuk, Bilal Khalid.

Formal analysis: Singha Chaveesuk, Bilal Khalid.

Investigation: Singha Chaveesuk, Bilal Khalid, Wornchanok Chaiyasoonthorn.

Methodology: Singha Chaveesuk, Bilal Khalid, Wornchanok Chaiyasoonthorn.

Resources: Singha Chaveesuk, Bilal Khalid, Wornchanok Chaiyasoonthorn.

Software: Bilal Khalid.

Validation: Singha Chaveesuk, Bilal Khalid, Wornchanok Chaiyasoonthorn.

Writing - original draft: Singha Chaveesuk, Bilal Khalid, Wornchanok Chaiyasoonthorn.

Writing - review, and editing: Singha Chaveesuk, Bilal Khalid, Wornchanok Chaiyasoonthorn.

\section{ACKNOWLEDGMENT}

This work is supported by King Mongkut's Institute of Technology Ladkrabang.

\section{REFERENCES}

1. Ajzen, I., \& Fishbein, M. (1980). Understanding attitudes and predicting social behavior. Englewood Cliffs: Prentice-Hall.

2. Akanfe, O., Rohit, V., \& Rao, H. R. (2019). GDPR fitness assessment for Digital Payment Systems' (DPS) privacy policies: A study of mobile wallet and remittance services. The 2019 Dewald Roode Workshop on Information Systems Security Research, 1-10.

3. Alaeddin, O., Altounjy, R., Zainudin, Z., \& Kamarudin, F. (2018). From physical to digital: Investigating consumer behaviour of switching to mobile wallet. Polish Journal of Management Studies, 17(2), 18-30. https://doi.org/10.17512/ pjms.2018.17.2.02

4. Al-Hujran, O., Al-Lozi, E., \& Al-Debei, M. M. (2014). Get ready to mobile learning: Examining factors affecting college students' behavioral intentions to use m-learning in Saudi Arabia. Journal of Business Administration, 10(1), 111-128. http://dx.doi. org/10.12816/0026186

5. Ali, R.A., \& Arshad, M.F.M. (2018). Empirical Analysis on Factors Impacting on Intention to Use M-learning in Basic Education in Egypt. International Review of Research in Open and Distributed Learning, 19(2). Retrieved from https://files.eric. ed.gov/fulltext/EJ1178661.pdf

6. Al-Mamoorey, M., \& Al-Rubaye, M. (2020). The role of electronic payment systems in Iraq in reducing banking risks: An empirical research on private banks. Polish Journal of Management Studies, 21(2), 49-59. https://doi. org/10.17512/pjms.2020.21.2.04

7. Al-Okaily, M., Lutfi, A., Alsaad, A., Taamneh, A., \& Alsyouf, A. (2020). The determinants of digital payment systems' acceptance under cultural orientation differences: The case of uncertainty avoidance. Technology in Society, 63, 101367. https://doi. org/10.1016/j.techsoc.2020.101367

8. Altounjy, R., Alaeddin, O., Hussain, H., \& Kot, S. (2020). Moving from bricks to clicks: Merchants' acceptance of the mobile payment in Malaysia. International Journal of EBusiness and EGovernment Studies, 12(2), 136-150. https://doi.org/10.34111/ijebeg.202012204

9. Chao, C. M. (2019). Factors Determining the Behavioral Intention to Use Mobile Learning: An Application and Extension of the UTAUT Model. Frontiers in Psychology, 16. https://doi.org/10.3389/ fpsyg.2019.01652
10. Chaveesuk, S., Khalid, B, \& Chaiyasoonthorn, W. (2019). Emergence of new business environment with big data and artificial intelligence. Proceedings of the 9th International Conference on Information Communication and Management, 181-185. https://doi. org/10.1145/3357419.3357441

11. Chaveesuk, S., Wutthirong, P., \& Chaiyasoonthorn, W. (2018). The model of mobile payment system acceptance on social networks in Thailand. Proceedings of the 2018 10th International Conference on Information Management and Engineering - ICIME 2018. https://doi. org/10.1145/3285957.3285990

12. Chen, S.-C., Li, S.-H., \& Li, C.-Y. (2011). Recent related research in Technology Acceptance Model: A literature review. Australian Journal of Business and Management Research, 1(9), 124-127. Retrieved from http://ajbmr.com/articlepdf/ AJBMR_19_04i1n9a14.pdf

13. Chin, L. P., \& Ahmad, Z. A. (2015). Perceived enjoyment and malaysian consumers' intention to use a single platform e-payment. SHS Web of Conferences, 18, 01009. https://doi. org/10.1051/shsconf/20151801009

14. Chiou, J. S., Cheng, H. I., \& Huang, C. Y. (2011). The effects of artist adoration and perceived risk of getting 
caught on attitude and intention to pirate music in the United States and Taiwan. Ethics \& Behavior, 21(3), 182 196. https://doi.org/10.1080/10508422 .2011 .570163

15. Cselényi, J., Smid, L., \& Kovács, G. (2002). Evaluation methods of storage capacity between manufacturing levels of EEES at changing product structure. MicroCAD 2002 International Scientific Conference. Miskolc, Hungary.

16. Dahlström, P., \& Edelman, D. (2013). The coming era of 'on-demand' marketing. McKinsey Quarterly, 2, 24-39.

17. Daragmeh, A., Sági, J., \& Zéman, Z. (2021). Continuous intention to use e-Wallet in the context of the COVID-19 pandemic: Integrating the Health Belief Model (HBM) and Technology Continuous Theory (TCT). Journal of Open Innovation: Technology, Market, and Complexity, 7(2), 132. https://doi.org/10.3390/joitmc7020132

18. Davis, F. D. (1989). Perceived usefulness, perceived ease of use, and user acceptance of information technology. MIS Quarterly, 13(3), 319. https://doi.org/10.2307/249008

19. DesRoches, C. M., Charles, D. Furukawa, M. F., Joshi, M. S., Kralovec, P., Mostashari, F., Worzala, C., \& Jha A. K. (2013). Adoption of electronic health records grows rapidly, but fewer than half of US hospitals had at least a basic system in 2012. Health Affairs, 32(8), 1478-1485. https://doi. org/10.1377/hlthaff.2013.0308

20. Ferguson, K. K., Soutter, L., \& Neubert, M. (2019). Digital payments in Africa - how demand, technology, and regulation disrupt digital payment systems. International Journal of Teaching and Case Studies, 10(4), 319. https://doi.org/10.1504/ ijtcs.2019.103771

21. Feyen, E., Frost, J., Gambacorta, L., Natarajan, H., \& Saal, M. (2021). Fintech and the digital transformation of financial services: implications for market structure and public policy (BIS Papers, No 117). Retrieved from https://www.bis.org/publ/bppdf/bispap117.pdf

22. Fichman, R., Dos Santos, B., \& Zheng, Z. (2014). Digital Innovation as a Fundamental and Powerful Concept in the Information Systems Curriculum. MIS Quarterly, 38(2), 329-A15. Retrieved August 10, 2021, from https://www.jstor.org/stable/26634929

23. Fishbein, M., \& Ajzen, I. (1975). Belief attitude, intention and behavior: An introduction to theory and research. Boston: Addison-Wesley.
24. Fornell, C., \& Larcker, D. F. (1981). Evaluating structural equation models with unobservable variables and measurement Error. Journal of Marketing Research, 18(1), 39-50. https://doi.org/10.2307/3151312

25. Goodrich, M., \& Boer, E. (2003). Model-based human-centered task automation: A case study in ACC system design. IEEE Transactions on Systems, Man, and Cybernetics Part A: Systems and Humans, 33(3), 325-336. https://doi.org/10.1109/ tsmca.2003.817040

26. Hoehle, H., Scornavacca, E., \& Huff, S. (2012). Three decades of research on consumer adoption and utilization of electronic banking channels: A literature analysis. Decision Support Systems, 54(1), 122-132. https://doi. org/10.1016/j.dss.2012.04.010

27. Hoque, R., \& Sorwar, G. (2017). Understanding factors influencing the adoption of mHealth by the elderly: an extension of the UTAUT model. International Journal of Medical Information, 101, 75-84. https://doi. org/10.1016/j.ijmedinf.2017.02.002

28. Howcroft, B., Hewer, P., \& Durkin, M. (2003). Banker-Customer Interactions in Financial Services. Journal of Marketing Management, 19(9-10), 1001-1020. https://doi.org/10.1080/026 7257x.2003.9728248

29. Hu, L.-t., \& Bentler, P. M. (1999). Cutoff criteria for fit indexes in covariance structure analysis: Conventional criteria versus new alternatives. Structural Equation Modeling, 6(1), 1-55. https://doi. org/10.1080/10705519909540118

30. Huang, H. M., \& Liaw, S. S. (2005). Exploring users' attitudes and intentions toward the web as a survey tool. Computers in Human Behavior, 21(5), 729-743. https://doi. org/10.1016/j.chb.2004.02.020

31. Hussein, Z. (2016). Leading to Intention: The Role of Attitude in Relation to Technology Acceptance Model in E-Learning. Procedia Computer Science, 105, 159-164.

32. Iqbal, S., \& Qureshi, I. A. (2012). M-learning adoption: A perspective from a developing country. The International Review of Research in Open and Distributed Learning, 13(3), 147-164.

33. Iskandar, Y.H.P., Subramaniam, G., Majid, M.I.A., Ariff, A.M., \& Rao, G.K.L. (2020). Predicting healthcare professionals' intention to use poison information system in a Malaysian public hospital. Health Information
Science and Systems, 8, 6. http://doi. org/10.1007/s13755-019-0094-0

34. Kankanhalli, S., \& Gomez, L. (2020, July 30). Why don't small retailers adopt e-payments? New research suggests the reasons behind merchant aversion - and solutions for stimulating customer demand. Next Billion. Retrieved from https:// nextbillion.net/why-dont-retailers-adopte-payments/

35. Khalid, B., Chaveesuk, S., \& Chaiyasoonthorn, W. (2021). MOOCS adoption in higher education: A management perspective. Polish Journal of Management Studies, 23(1), 239-256. https://doi.org/10.17512/ pjms.2021.23.1.15

36. Khalid, B., Lis, M., Chaiyasoonthorn, W., \& Cheevasuk, S. (2021). Factors influencing behavioral intention to use MOOCs. Engineering Management in Production and Services, 13(2), 83-95.

37. Kleczkowski, A., Maharaj, S., Rasmussen, S., Williams, L., \& Cairns, N. (2015). Spontaneous social distancing in response to a simulated epidemic: a virtual experiment. $B M C$ Public Health, 15, 973. https://doi. org/10.1186/s12889-015-2336-7

38. Kovács, G., Cselényi, J., \& Somogyvári, Z. (2007). Method and conception formation of microregional virtual logistics networks. OGET 2007 International Engineering Conference, 216-221. Cluj-Napoca, Romania. (In Romanian).

39. Ligon, E., Malick, B., Sheth, K., \& Trachtman, C. (2019). What explains low adoption of digital payment technologies? Evidence from smallscale merchants in Jaipur, India. PLOS ONE, 14(7), e0219450. https://doi. org/10.1371/journal.pone.0219450

40. Lin, Wan R., Lin, C.-H., \& Ding, Y.-H. (2020). Factors affecting the behavioral intention to adopt mobile payment: An empirical study in Taiwan. Mathematics, 8(10), 1851. https://doi. org/10.3390/math8101851

41. Macheel, T. (2017, February 3). Why retailers struggle to adopt mobile payments. Digiday. Retrieved from https://digiday.com/marketing/ retailers-struggling-adopt-mobilepayments/

42. Montazemi, A. R., \& Qahri-Saremi, H. (2015). Factors affecting adoption of online banking: A meta-analytic structural equation modeling study. Information \& Management, 52(2), 210-226. https://doi.org/10.1016/j. im.2014.11.002

43. Muangmee, C., Kot, S., Meekaewkunchorn, N., Kassakorn, 
N., \& Khalid, B. (2021). Factors determining the behavioral intention of using food delivery apps during COVID-19 pandemics. Journal of Theoretical and Applied Electronic Commerce Research, 16(5), 1297-1310. https://doi.org/10.3390/jtaer16050073

44. Nathues, E. (2017). From interruption to interaction: Inspiration as a new marketing discipline. In E. Constantinides, \& S. de Vries (Eds.), Marketing of the 21st Century Marketing Science Institute Research priorities 2016-2020 through the lens of the future marketer (pp. 38-48). University of Twente. Retrieved from https://www.utwente.nl/repository/ utwente-data/ut_central/en/press $\% 20$ department $\% 20$-\%20widgets\%20 bij\%20news\%20items/2017/volume-1 essays-on-msi-themes-ut-class-201617-jan-2017.pdf

45. Nwaolisa, E. F., \& Kasie, E. G. (2012). Electronic retail payment systems User acceptability and payment problems in Nigeria. Oman Chapter of Arabian Journal of Business and Management Review, 1(6), 18-35. https://doi.org/10.12816/0002106

46. Pearce, K. (2020, March 13). What is social distancing and how can it slow the spread of COVID-19? Retrieved from https://hub.jhu.edu/2020/03/13/ what-is-social-distancing/kiki

47. Peñarroja, V., Sánchez, J., Gamero, N., Orengo, V., \& Abad, A. Z. (2019). The influence of organisational facilitating conditions and technology acceptance factors on the effectiveness of virtual communities of practice. Behavior \& Information Technology, 38, 845857. https://doi.org/10.1080/014492 9X.2018.1564070

48. Pikkarainen, T., Pikkarainen, K., Karjaluoto, H., \& Pahnila, S. (2004). Consumer acceptance of online banking: an extension of the technology acceptance model. Interne Research, 14(3), 224-235. https://doi. org/10.1108/10662240410542652

49. Raharja, S. ' J., S., Muhyi, H. A. \& Herawaty, T. (2020). Digital payment as an enabler for business opportunities: A go-pay case study. Review of Integrative Business and Economics Research, 9(1), 319-329. Retrieved from http://buscompress. com/uploads/3/4/9/8/34980536 riber_9-s1_25_b19-102_319-329.pdf

50. Rangaswamy, A., Moch, N., Felten, C., van Bruggen, G., Wieringa, J. E., \& Wirtz, J. (2020). The role of marketing in digital business platforms. Journal of Interactive Marketing, 51, 72-90. https://doi.org/10.1016/j.intmar.2020.04.006
51. Roboff, G., \& Charles, C. (1998). Privacy of financial information in cyberspace: banks addressing what consumers want. Journal of Retail Banking Services, XX(3), 51-60.

52. Sanayei, A., \& Noroozi, A. (2009). Security of internet banking services and its Linkage with Users' Trust: A Case Study of Parsian Bank of Iran and CIMB Bank of Malaysia. 2009 International Conference on Information Management and Engineering. https://doi.org/10.1109/ icime.2009.153

53. Sang, G. Y., Valcke, M., van Braak, J., \& Tondeur, J. (2010). Student teachers' thinking processes and ICT integration: Predictors of prospective teaching behaviors with educational technology. Computers \& Education, 54(1), 103-112. https://doi. org/10.1016/j.compedu.2009.07.010

54. Scholnick, B., Massoud, N., Saunders, A., Carbo-Valverde, S., \& RodríguezFernández, F. (2008). The economics of credit cards, debit cards and ATMs: A survey and some new evidence. Journal of Banking \& Finance, 32(8), 1468-1483. https://doi.org/10.1016/j. jbankfin.2007.05.001

55. Seethamraju, R., \& Diatha, K. S. (2018). Adoption of digital payments by small retail stores. Australasian Conference on Information Systems. Sydney, Australia. Retrieved from http://www.acis2018.org/wp-content/ uploads/2018/11/ACIS2018_paper_96.pdf

56. Seethamraju, R., \& Diatha, K.S (2019). Digitalization of small retail stores - challenges in digital payments. Proceedings of the 52nd Hawaii International Conference on System Sciences, HICSS 2019. Grand Wailea, Maui, Hawaii, USA. Retrieved from https://scholarspace.manoa.hawaii. edu/bitstream/10125/59954/0514.pdf

57. Shiau, W.-L., \& Chau, P. Y. K. (2016). Understanding behavioral intention to use a cloud computing classroom: a multiple model comparison approach. Cell, 53, 355-365. https://doi. org/10.1016/j.im.2015.10.004

58. Singh, S., \& Rana, R. (2017). Study of consumer perceptive of digital payment mode. Journal of Internet Banking and Commerce, 22(3), 1-14.

59. Sivathanu, B. (2019). Adoption of digital payment systems in the era of demonetization in India. Journal of Science and Technology Policy Management, 10(1), 143-171. https:// doi.org/10.1108/jstpm-07-2017-0033

60. Solomon, E. M., \& van Klyton, A. (2020). The impact of digital technology usage on economic growth in Africa. Utilities Policy, 67, 101104. https://doi.org/10.1016/j. jup.2020.101104

61. Staykova, K. S., \& Damsgaard, J. (2016). Adoption of mobile payment platforms: managing reach and range. Journal of Theoretical and Applied Electronic Commerce Research, 11(3). http://dx.doi.org/10.4067/S071818762016000300006

62. Technology and Innovation Report. (2018). Harnessing Frontier Technologies for Sustainable Development. United Nations Conference on Trade and Development. Retrieved from https://unctad.org/ system/files/official-document/ tir2018_en.pdf

63. Teo, T., Lee, C. B., Chai, C. S., \& Wong, S. L. (2009). Assessing the intention to use technology among pre-service teachers in Singapore and Malaysia: A multigroup invariance analysis of the technology acceptance model. Computers \& Education, 53(3), 1000-1009. http://dx.doi.org/10.1016/j. compedu.2009.05.017

64. Tounekti, O., Ruiz-Martinez, A. \& Skarmeta Gomez, A. F. (2020). Users supporting multiple (mobile) electronic payment systems in online purchases: An empirical study of their payment transaction preferences. IEEE Access, 8, 735-766. https://doi. org/10.1109/access.2019.2961785

65. Venkatesh, V., Morris, M. G., Davis, G. B., \& Davis, F. D. (2003). User acceptance of information technology: toward a unified view. MIS Quarterly, 27, 425-478.

66. Wei, Y., Wang, C., Zhu, S., Xue, H., \& Chen, F. (2018). Online purchase intention of fruits: antecedents in an integrated model based on technology acceptance model and perceived risk theory. Frontiers in Psychology, 9, 1521. https://doi.org/10.3389/ fpsyg.2018.01521

67. Williams, M. D., Rana, N. P., \& Dwivedi, Y. K. (2015). The Unified Theory of Acceptance and Use of Technology (UTAUT): A literature review. Journal of Enterprise Information Management, 28(3), 443 488. https://doi.org/10.1108/jeim-092014-0088

68. Wong, W. H., \& Mo, W. Y. (2019). A study of consumer intention of mobile payment in Hong Kong, based on perceived risk, perceived trust perceived security and Technological Acceptance Model. Journal of Advanced Management Science, 7(2), 33-38. https://doi.org/10.18178/ joams.7.2.33-38 
69. Yang, M., Mamun, A. A., Mohiuddin, M., Nawi, N. C., \& Zainol, N. R.

(2021). Cashless transactions: A study on intention and adoption of e-Wallets. Sustainability, 13, 831. https://doi. org/10.3390/su13020831

70. Yang, S., Lu, Y., Gupta, S., Cao, Y., \& Zhang, R. (2012). Mobile payment services adoption across time: An empirical study of the effects of behavioral beliefs, social influences, and personal traits. Computers in Human Behavior, 28(1), 129

142. https://doi.org/10.1016/j. chb.2011.08.019

71. Yi, M. Y., Jackson, J. D., Park, J. S., \& Probst, J. C. (2006). Understanding information technology acceptance by individual professionals? Toward an integrative view. Information \& Management, 43(3), 350-363. https:// doi.org/10.1016/j.im.2005.08.006

72. Yu, H. C., Hsi, K. H., \& Kuo, P. J. (2002). Electronic payment systems: an analysis and comparison of types. Technology in Society, 24(3), 331-

347. https://doi.org/10.1016/s0160$791 \mathrm{x}(02) 00012-\mathrm{x}$

73. Zhang, X., \& Yu, X. (2020). The Impact of Perceived Risk on Consumers' Cross-Platform Buying Behavior. Frontiers in Psychology, 11 2835. Retrieved from https://www. frontiersin.org/articles/10.3389 fpsyg.2020.592246/full 